\title{
Monetary and Financial Developments
}

$\mathbf{T}$

HE CRUCIAL problem for stabilization policy at this time is how to achieve the most tolerable trade-off between continued downward pressure on the rate of price increase and slack in economic activity. Excluding the effects of the automobile strike, total production is apparently increasing slightly, and a slow recovery seems in prospect. There is also evidence that the rate of price advance has begun to decelerate.

A repeat of the 1967 experience, when spending was excessively stimulated and inflation intensified by an overreaction by monetary authorities to some cutbacks in output, must be avoided. Two factors which make such a recurrence unlikely are that monetary growth this year has not been so rapid as in 1967, and the economy today is not so close to full capacity. However, the strong expectations of price increases that still prevail will probably allow only gradual decline in the rate of price increase.

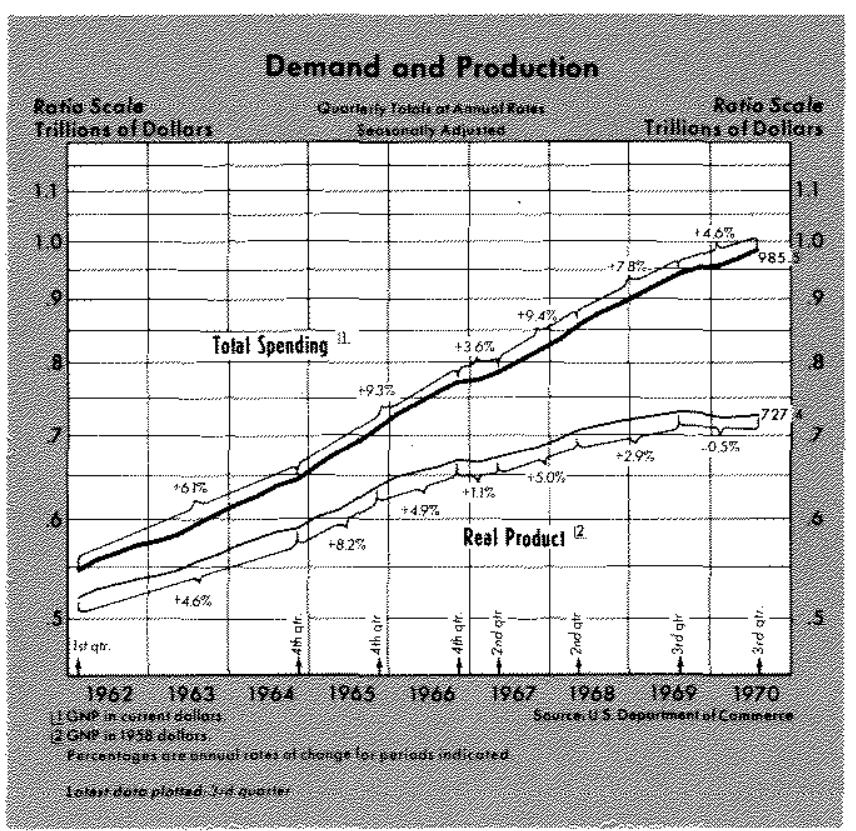

Total spending has increased 4.6 per cent since the third quarter of 1969 , compared with an 8.5 per cent average annual rate in the preceding two years. Real product has changed little on balance since the third quarter of 1969 , compared with growth of 2.6 per cent in the preceding year and a 5 per cent rate from 1965 to 1968 .

Industrial production declined abruptly in September and again in October, after drifting down 3 per cent in the preceding year. The substantial drop in industrial production from August to October is attributable largely to the auto strike which began in mid-September. By comparison industrial production rose at about a 5.7 per cent average annual rate from mid-1967 to mid-1969.

The inflation experienced since the mid-Sixties has stopped accelerating and apparently is moderating.

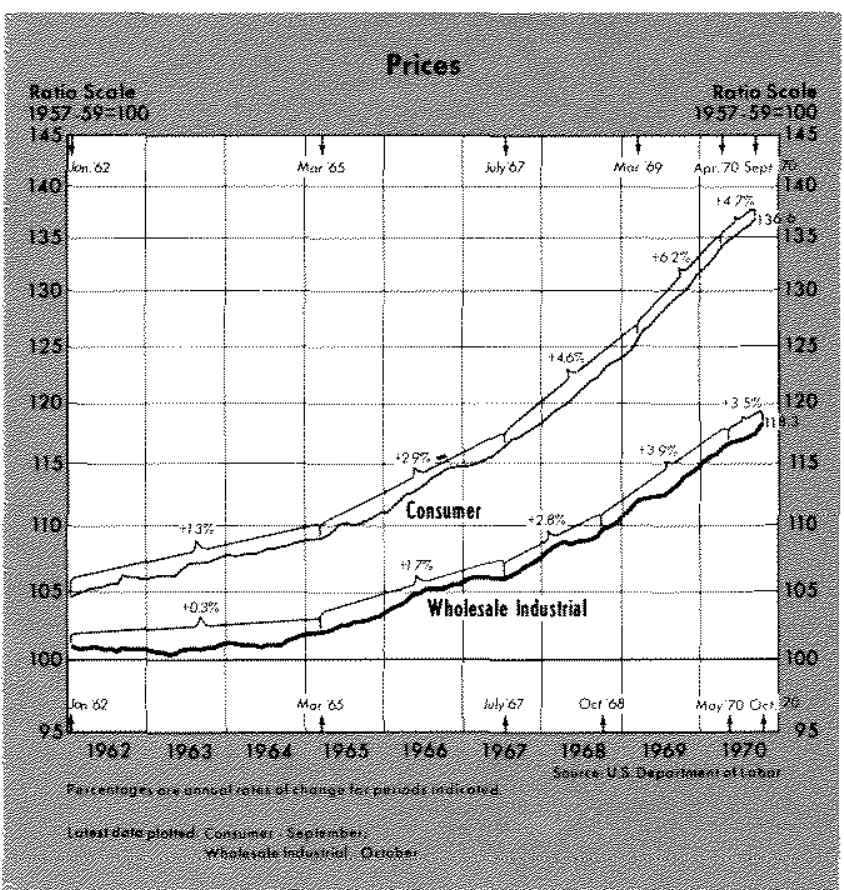


This improvement is a lagged response to the markedly slower growth of total spending, which began in late 1969 in response to restrictive monetary policy initiated in early 1969. Consumer prices increased at a 4.7 per cent annual rate from April to September, compared with a 6 per cent increase during the previous 12 months. Wholesale prices of industrial commodities rose at a 3.5 per cent rate from May to October, compared with about a 4 per cent rise in the preceding year. Overall prices (GNP deflator) rose at a 4.4 per cent rate from the first to the third quarter of 1970 , down from the 5.5 per cent inflation in the preceding year. An index of prices of $13 \mathrm{raw}$ industrial commodities has declined at about an 11 per cent rate since early this year.

\section{Monetary Aggregates}

The restraint on total spending during the past year has been fostered by monetary restraint in 1969 . The money stock was about unchanged from June 1969 to February 1970. Since February, the money stock has increased at about a 5 per cent annual rate. Previous to the restraint of 1969 , money growth had accelerated from a 2 per cent trend rate in the 1953-65 period, to a 4 per cent trend rate in the 1965-67 period, and a 7 per cent rate during 1967 and 1968 .

The recent growth of money has been relatively rapid by historical standards, but in view of the recent strong inflation a relatively rapid monetary growth rate perhaps has been appropriate. In the long run it may be desirable for total spending to rise at only about a 4 or 4,5 per cent annual rate to foster maximum attainable real growth without inflation, but a somewhat faster growth in spending may be temporarily desirable because of inflationary expectations which cannot be changed quickly. Total spending growth at a 6 or 7 per cent rate, higher than the most desirable rate in the long run, might permit a larger expansion in real output and more employment opportunities during the transition period to a lower rate of inflation.

A turn to moderate monetary expansion was undertaken by the System's Open Market Committee at its January and February meetings, when its directive to the operating manager expressed a "desire to see a modest growth in money and bank credit." ${ }^{11}$ The di-

1 At the February meeting of the FOMC, the word "modest" was changed to "moderate," and this has been tused in subsequently published directives (through July meeting). Each month's directive is published, with a three-month lag, in the Federal Reserve Bulletin, Board of Governors, Washington, D. C. rectives in late 1969 had included no direct reference to money, and had stated that monetary policies "shall be conducted with a view to maintaining the prevailing firm conditions in the money markets." This language could be interpreted to mean that no relaxation of monetary policy was to be attempted at the time. Directives published by the FOMC since January (through the July meeting) have all stated a desire for "moderate" growth of money and bank credit.

February seems to be an appropriate base month for calculating the recent rate of growth in money, because this was about the time of the definite change in the policy directive of the FOMC, and because this seems to be the dividing line between a period of no money growth and a period of sustained growth. Other possible base points, such as January

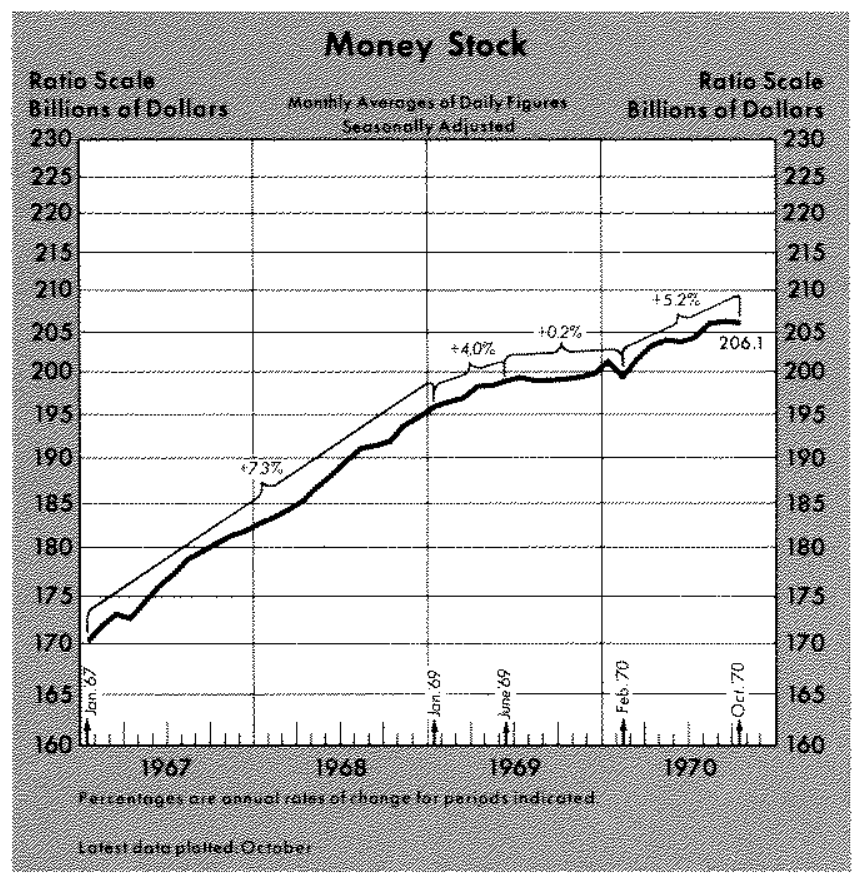

and late March or April, which contain large temporary jumps in the money stock, would provide a relatively poor base for determining a trend.

In the "rate of change" table for the money stock on the next page, compounded annual rates of change from various initial months to various terminal months are displayed, permitting the user to read the rate of change between any two points in time of the months covered. The table, which is similar to a mileage table on road maps, can be read by choosing an initial month at the top and a terminal month at the left side, so that the rate of change between the two months selected is found at the intersection of the column of the initial month and the row of the ter- 


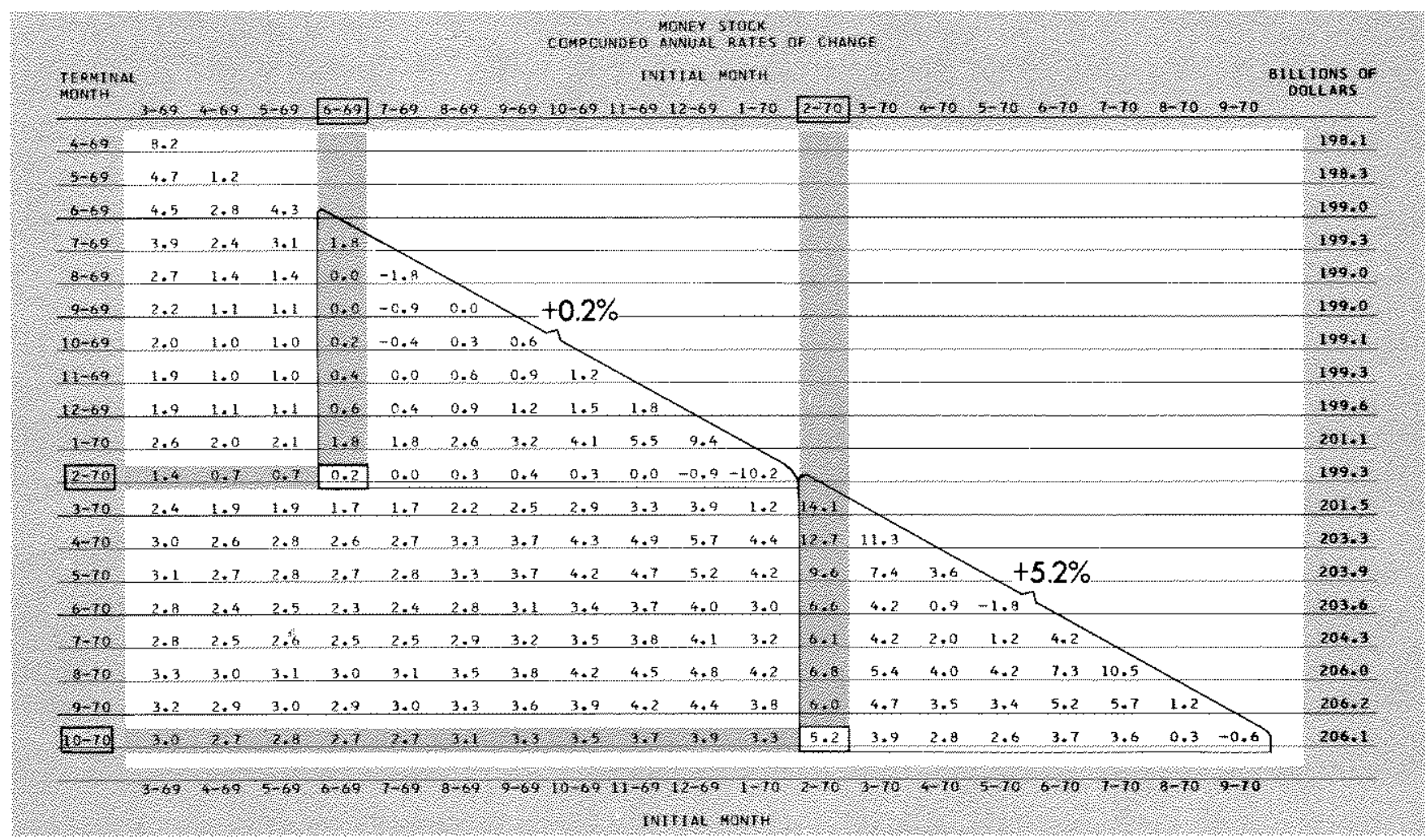

minal month. For example, the 5.2 per cent annual rate of increase in money from February to October is denoted in the table, and the same figure is shown on the money stock chart as the last bracketed figure. The column of numbers at the far right gives the actual average stock of money for each of the terminal months. Each figure along the diagonal edge of the table represents the rate of change from one month to the following month. ${ }^{2}$

The demand deposit component, which comprises about three-fourths of the money stock, has increased at a 4.5 per cent annual rate since February. By comparison, this magnitude decreased at a 1.2 per cent rate from June 1969 to February 1970. The currency component has increased at a 6.9 per cent rate during the past eight months, after increasing at a 5.4 per cent during the previous eight months.

Member bank reserves, which underlie bank credit and the money supply, have increased at a 9.1 per cent annual rate in the past eight months. Federal Reserve credit, the most important determinant of bank reserves, has increased at a 7.9 per cent rate

${ }^{2}$ This Bank's Monetary Trends and National Economic Trends contain similar tables each month on selected financial data. More up-to-date rates of change regarding financial data are presented each week in this Bank's U.S. Financial Data. To receive these publications, write: Research Department, Federal Reserve Bank of St. Lous, P.O. Box 442, St. Louis, Missouri 63166. since February compared with a 1 per cent rate from June 1969 to February 1970.

Money stock plus time deposits, a broader concept of money which has largely lost its significance in recent years, has increased at a 14 per cent annual rate since February. This aggregate declined at a 3.2 per cent rate during the previous eight months when the money stock was essentially unchanged and disintermediation was occurring. Exclusive of large certificates of deposit, this measure has grown at a 9.4 per cent rate since February, after declining at a 1.3 per cent rate over the previous eight months. Some analysts feel this latter refinement of the measure may be more useful, since the volume of large CD's is most heavily influenced by the fluctuating relationship between Regulation $Q$ ceilings and short-term market interest rates. Time deposits, other than large CD's, include primarily passbook savings and savings certificates.

Bank credit has increased at a 9.5 per cent annual rate from February to October, compared with about a 1 per cent rate from May 1969 to February 1970, a period of disintermediation and no monetary growth. Since February, bank loans have increased at a 5.2 per cent rate as demand has been moderate. Over the same period, total investments held by banks have increased at about a 19 per cent rate. The banks thereby have been able to take advantage of 


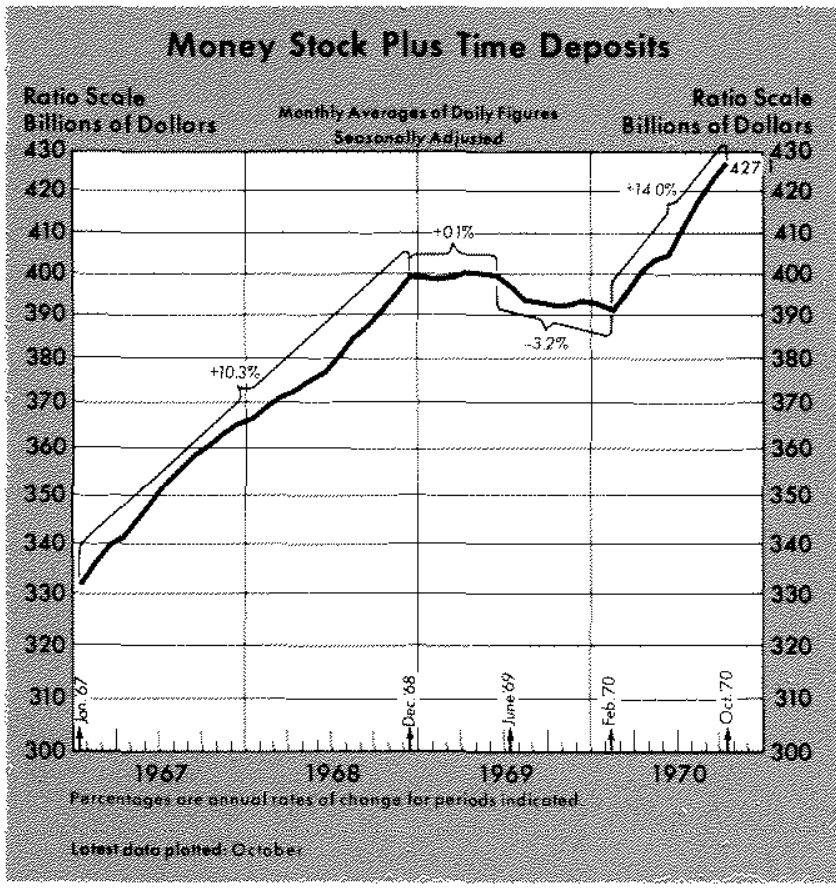

the reintermediation and monetary expansion to rebuild their liquidity positions, which fell in 1.969 when bank investments declined at about a 6 per cent rate.

Short- and intermediate-term interest rates have fallen rapidly in 1970 , reflecting both the more rapid monetary expansion and a slowing in demand for loan funds. Yields on three-month Treasury bills averaged 5.57 per cent and four- to six-month commercial paper averaged 6.60 per cent in the first half of November, both down about $2^{1 / 4}$ percentage points since January. Interest rates on three- to five-year Government securities declined from 8.14 per cent in January to 6.76 per cent in the first half of November.

Responding to the same supply and demand conditions as money market rates but usually with some lag, the prime rate has been lowered three times so far in 1970. The rate was lowered in March from $8^{1 / 2}$ per cent to 8 per cent, in September to $7 \frac{1 / 2}{2}$ per cent and, in November to $7^{1 / 4}$ per cent. Following the changes in other interest rates, the rate which Federal Reserve banks charge on loans to member banks was reduced from 6 per cent to $5^{3 / 4}$ per cent this month.

\section{Financial Intermediaries}

At the same time that the money stock has risen more rapidly since early this year, there has also been a large inflow of time deposits to banks and to nonbank savings institutions. As a result, total liquid assets of the public, as generally measured, have risen more rapidly in 1970 than in 1969. Part of the increase in funds at savings institutions probably represents new saving by consumers and businesses, but much reflects a redirecting of existing funds from nonfinancial intermediary markets, such as commercial paper, Eurodollars, and trade and individual credit.

Time deposits in commercial banks are not homogeneous assets, but rather consist of several different types of accounts, with different interest rate ceilings, minimum amount requirements, and time-to-maturity restriction. These different categories have grown at markedly different rates. Large CD's at commercial banks after dropping $\$ 13.1$ billion from December 1968 to January 1970 have increased 12.6 billion since January.

Total time deposits at commercial banks have increased at a 23.5 per cent annual rate since February, after declining at a 5 per cent rate during the preceding year. Time deposits other than the large CD's have increased at a 14 per cent rate since February, after declining at about a 3 per cent rate from June 1969 to February 1970.

Net flows of funds into saving and loan associations and mutual saving banks have been substantial in 1970 , but less rapid than the flow of time money other than large CD's into commercial banks. Since February saving and loan shares have increased at a 10 per cent annual rate and mutual saving bank deposits at a 6.8 per cent rate. These rates compare with a 0.6 per cent rate for savings and loan shares and a 2.6 per cent rate for mutual savings banks deposits in the previous eight months.

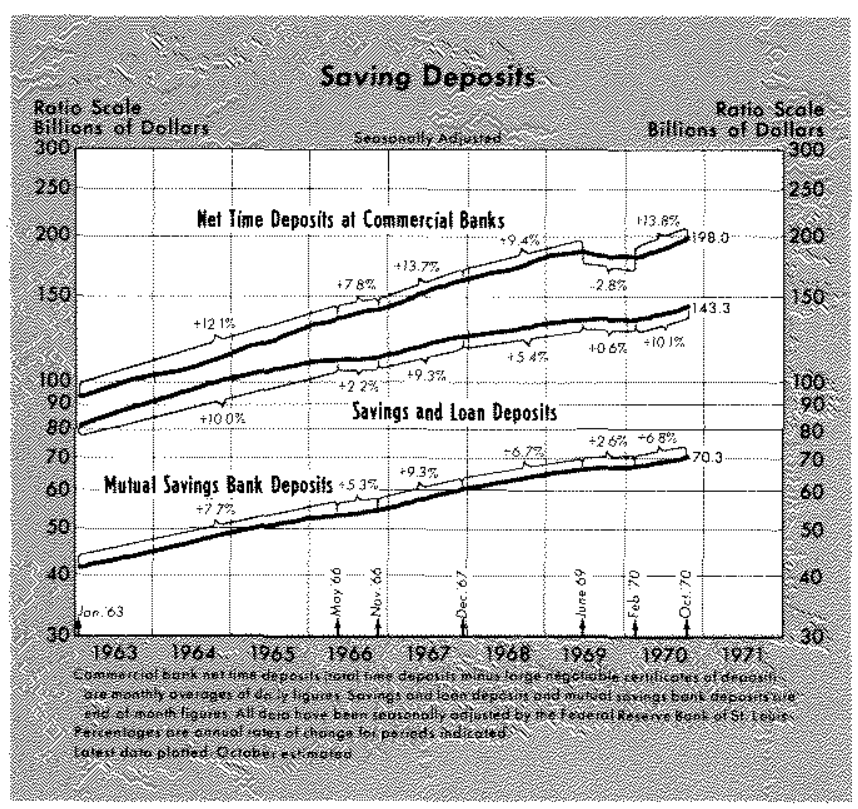


This inflow of saving funds seems to have helped the mortgage markets even though mortgage interest rates have declined little. Private housing starts have increased from a 1.3 million seasonally adjusted annual rate in the first quarter to a 1.5 million rate in the third quarter. By comparison, this measure decreased from a 1.7 million rate to the 1.3 million rate in the preceding year.

The slow growth of savings funds at both bank and nonbank financial intermediaries from June 1969 to February 1970 can be attributed to high market rates and fixed ceilings on interest rates that could be paid by financial intermediaries. As market interest rates rose in 1969 , the ability of financial intermediaries to compete for funds was constrained by the maximum interest rates they were permitted to offer under Regulation $Q$ and the corresponding regulations of the Federal Deposit Insurance Corporation and the Federal Home Loan Bank Board.

Since January, the disintermediation which occurred in 1969 has been reversed, as market interest rates have declined and Regulation $Q$ ceilings have been raised $1 / 2$ to $3 / 4$ percentage points in most categories. Maximum interest rate ceilings for saving and loan associations regulated by the Federal Home Loan Bank were also raised and differentiated as to type of account, maturity, and amount. In addition, Regulation Q ceilings on 30- to 89. day maturity large CD's were suspended in June, allowing banks to compete once again with market interest rates, and, as a result the volume of CD's has grown rapidly.

\section{Federal Budget Developments}

Federal Government spending on a national income accounts basis has risen at a 7 per cent annual rate since the second quarter of 1969 , compared with 5 per cent in the previous year and a 15 per cent average annual rate from mid-1965 to mid-1968. The share of Federal expenditures for defense has declined since the second quarter of 1969, as defense expendittrres have declined at about at 2 per cent anmual rate while nondefense expenditures have increased at a 14 per cent rate. By comparison, from mid-1965 to mid-1968 defense and non-defense expenditures rose at rates of 17 and 13 per cent.

The national income accounts budget has moved sharply from the $\$ 9$ billion surplus in 1969 to a deficit at about a $\$ 13$ billion annual rate in the second and third quarters of 1970 . Although the 10 per cent surtax expired and Federal expenditures rose rapidly, using our concept of full employment, approximately
$\$ 16$ billion of the shift in the NIA budget can be attributed to the slowdown in the economy. Approximately $\$ 14$ billion of the change was due to the loss of receipts resulting from the slowdown in personal income and corporate profits, and about $\$ 2$ billion was due to expenditures for unemployment benefits. It is estimated that a deficit at about an $\$ 11$ billion annual rate is being incurred in the fourth quarter of 1970.

The high-employment budget has shown a somewhat different picture of the Federal budget than the national income accounts budget because of the slowdown in the economy. An estimate of the Federal budget surplus or deficit at a constant level of resource utilization provides a measure of changes in the budget due to changes in the tax laws and to Congressional provisions for Federal expenditures. This budget shows a surplus at about a $\$ 4$ billion annual rate in the second and third quarters and an estimated surplus at about a $\$ 7$ billion annual rate in the fourth quarter. This compares with an average surplus at about an $\$ 11$ billion rate from the second quarter of 1969 to the first quarter of 1970 . The budget outlook for the first half of 1971 is for a surplus at an annual rate of about $\$ 10$ billion. This estimate assumes the effects of the proposed speed-up in collections of estate and gift taxes and the new tax on lead used in gasoline will appear in the first half of 1971 , and that growth of expenditures through

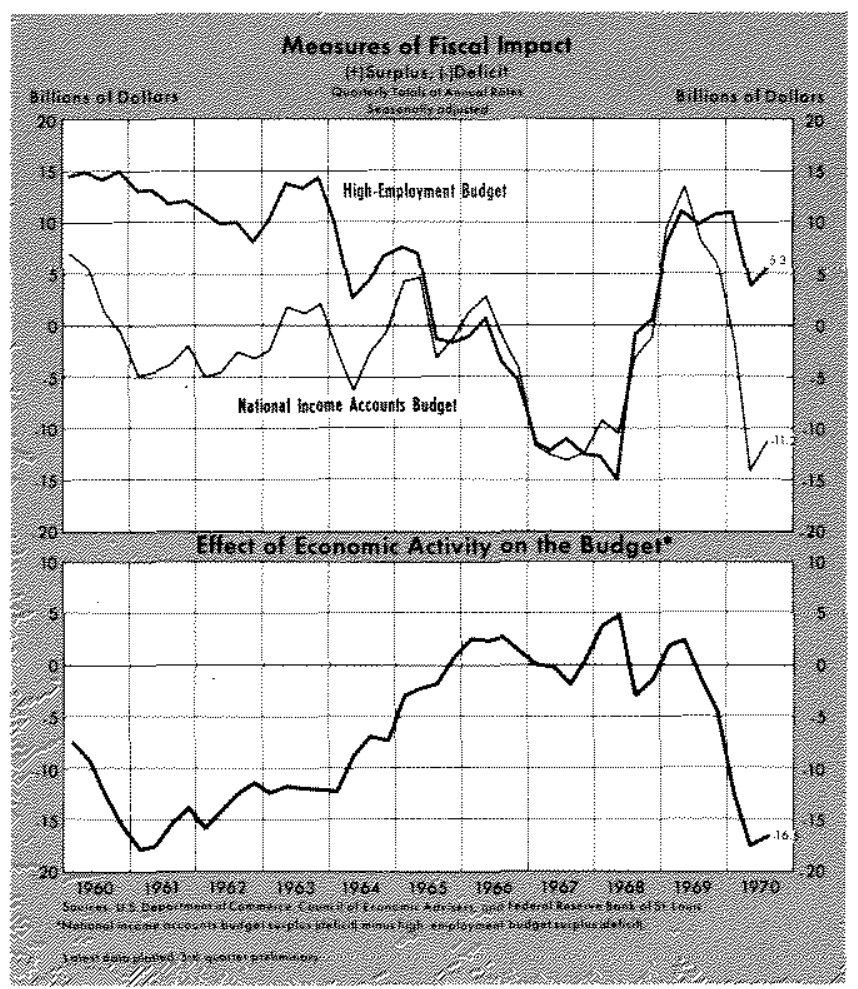




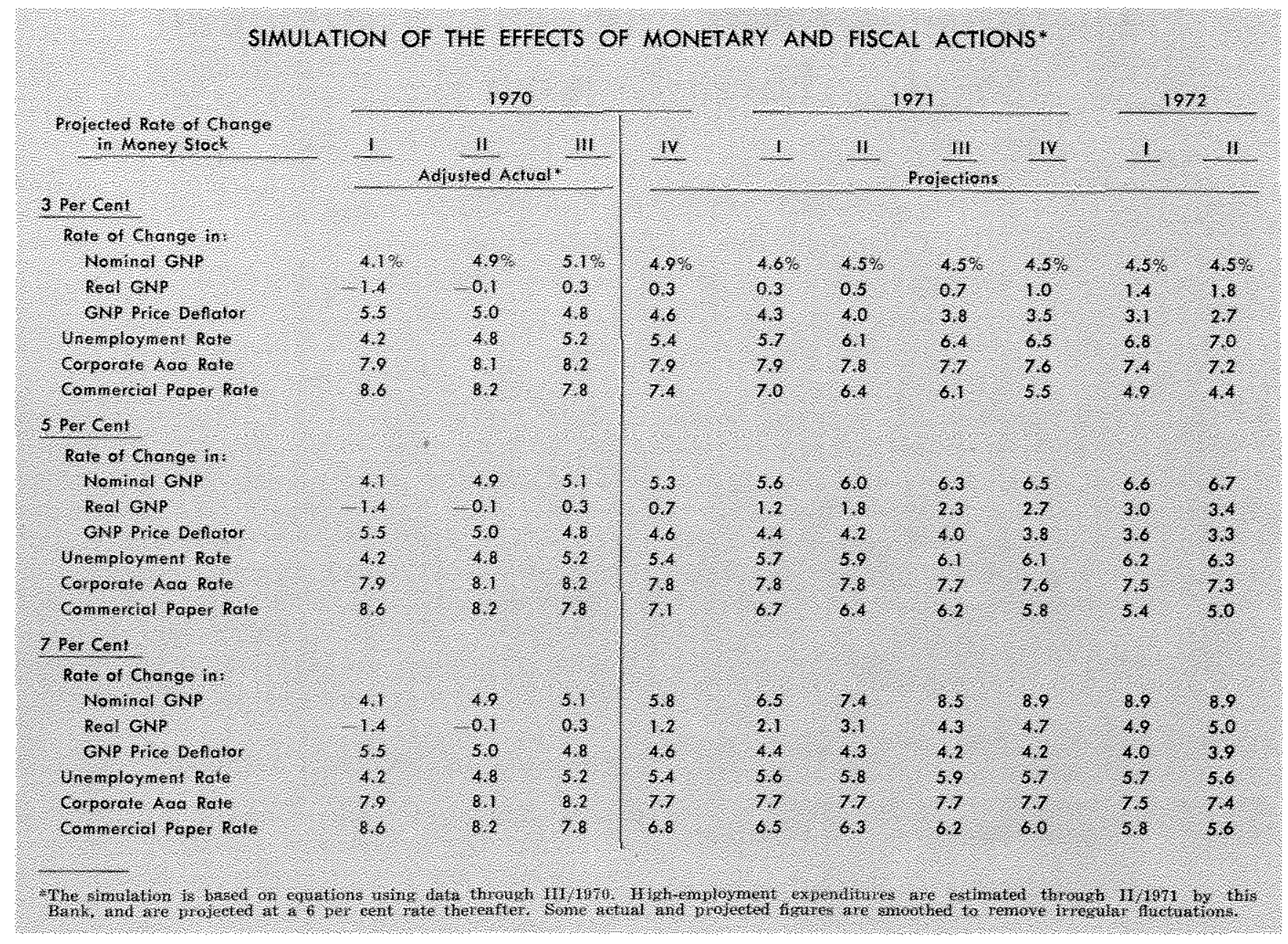

the second quarter of 1971 will continue at about the same rate as over the past 5 quarters.

\section{Projections}

Using this bank's model as presented in the April 1970 Review, various assumed alternative rates of change of money can be used to project rates of change in spending, real product, and prices. ${ }^{3}$ If a 5 per cent rate of money growth were to be followed from now until the fourth quarter of next year, total spending might be growing at about a 6.5 per cent amnual rate a year hence, compared with about a 5.3 per cent rate now. With this growth in total spending, prices might be rising at about a 3.8 per cent rate, compared with a 4.6 per cent rate now. Real output would be expanding at an estimated 2.7 per cent rate, compared with little growth at present.

\footnotetext{
3See "A Monetarist Model for Economic Stabilization," this Review (April, 1970), pp. 7-25. For current simulations see Quarterly Economic Trends, prepared by this Bank.
}

If a slower 3 per cent rate of growth in money were followed until the fourth quarter of next year, total spending would probably be advancing at a more moderate 4.5 per cent rate a year hence. Real output would be advancing at a 1 per cent rate, up slightly from the present rate. The rate of price increase would probably decrease about 1 percentage point from the current rate to a 3.5 per cent rate. Alternatively, if a faster 7 per cent rate of money growth were followed, total spending would be growing at a rapid 9 per cent rate a year hence, and real product at about a 4.7 per cent rate. Price trends, however, would show little improvement relative to the present situation.

These altemative rates of money growth all imply some expansion in real output and continued inflation. Choice depends upon the real growth we are willing to give up transitionally in order to move more rapidly toward a lower rate of inflation. 